\title{
HUBUNGAN TAYANGAN KEKERASAN DI TELEVISI DENGAN PRESTASI BELAJAR SISWA DI SEKOLAH DASAR
}

\author{
Dewi Septiani Mandasari
}

STKIP PGRI Bangkalan

Email: dewiseptiani0701@yahoo.com

\begin{abstract}
ABSTRAK
Setiap proses belajar akan menghasilkan perubahan tingkah laku siswa yang mengalami proses tersebut. Bagi para siswa di sekolah sekolah, pembinaan moral ini dan sosial dapat dilakukan melalui studi formal, serta unsur unsur yang dapat meneruskan dan mengembangkan jiwa dan semangat dan nilai nilai 1945 kepada generasi muda harus makin ditingkatkan dalam kurikulum serta lingkungan masyarakat.Ada banyak hal yang dapat mengakibatkan seorng anak berperilaku untuk meniru apa yang yang telah dilihat maupun ditontonnya. Salah satunya adalah tayangan kekerasan di media elektronik atau televisi. Tayangan kekerasan di teleisi secara langsung dapat mempengaruhi perilaku anak untuk menirunya karena anak belum tahu apa yang dilihatnya tersebut adalah benar atau salah. Hipotesa penelitian ini adalah "Hubungan tanyangan kekerasan teleisi dengan prestasi Belajar siswa di sekolah siswa di SDN Lerpak 3 Kecamatan Geger Kabupaten Bangkalan" Metode yang digunakan adalah metode dokumentasi, observasi dan angket yang menunjang kedua variabel. Maka untuk mengetahui hipotesis yang diajukan diterima atau ditolak maka menggunakan rumu korelasi poduct moment. Dalam hasil hitungan data tersebut dapat diketahui bahwa $t=$ hitung $+2,88$ sedangkan menurut taraf signifikan 5\%=2,04 dan 1\%=2,75. Dengan demikian nilai thitung lebih besar dari t tabel pada taraf signifikan 5\% sehingga hipotesa kerja ( $\mathrm{Ha}$ ) dapat diterima, sedangkan hipotesa nihil (Ho) ditolak artinya ada hubungan tayangan kekerasa teleisi dengan prestasi belajar siswa di sekolah dasar
\end{abstract}

Kata Kunci : kekerasan di televisi, prestasi belajar, siswa sekolah dasar 


\title{
EASILY VIOLENCE RELATIONSHIP AT TELEVISION WITH ACHIEVEMENT STUDENT LEARNING IN BASIC SCHOOL
}

\author{
Dewi Septiani Mandasari \\ STKIP PGRI Bangkalan \\ Email: dewiseptiani0701@yahoo.com
}

\begin{abstract}
Each learning process will result in changes in the behavior of students who experience the process. For students in school schools, this moral and social coaching can be done through formal study, as well as elements that can continue and develop the soul and developing soul and spirit and value value 1945 to the younger generation should be improved in the curriculum and community environment. There are many things that can result in a child behaving to imitate what he has seen or seen. One of them is the violence in electronic or television media. Impressions of violence in teleisi can directly affect a child's behavior to imitate him because the child does not yet know what he or she is seeing is true or false. The hypothesis of this research is "The correlation between the teleisi violence with the achievement of student learning in the student's school in SDN Lerpak 3 Kecamatan Geger Kabupaten Bangkalan" The method used is the method of documentation, observation and questionnaire that support both variables. So to find the proposed hypothesis accepted or rejected then use rumus correlation poduct moment. In the results of the data count can be seen that $t=$ count 2,88 whereas according to the significant level 5\%=2,04 and 1\%=2,75 Thus the value of $t$ arithmetic greater than $t$ table at a significant level 5\% so that the working hypothesis ( $\mathrm{Ha}$ ) is acceptable, while the null hypothesis (Ho) is rejected means that there is a connection of teleisi teleisi impression with the achievement of students in primary school.
\end{abstract}

Keywords: violence on television, learning achievement, elementary school students.

\section{PENDAHULUAN}

Sejak anak lahir di dunia pertama tama mengenal lingkungan sekelilingnya adalah keluarga, maka yang paling pertama dikenalnya dalah ibunya, kemudian ayahnya dan selanjutnya mengenal lebih luas lagi tentang sesuatu yang berada di sekitarnta. Kita mengetahui bahwa anak lahir dalam keadaan lemah dan tidak berdaya, karena itu dia memerlukan bantuan dengan orang lain. Proses pendidikan dapat berlangsung dalam lingkungan . Disamping dituntut dapat berperan di lingkungan masing masing setiap pendidikan hendaknya juga dapat bekerja sama dengan pendidikan di lingkungan lain, sebab setiap lingkungan pendidikan sebenarnya merupakan komponem system lingkungan pendidikan.Pada umumnya kita hanya melihat sepintas bahwa pendidikan seakan akan hanya berlangsung di sekolah dan secara kelembagaan tidak ada pengaruh yang 
berartti dari unsure unsure lain. Sekolah merupakan lingkungan pendidikan yang terorganisasi dengan secara kelembagaan.

Dampak efek komunikasi massa bisa di bagi dua:efek yang bersifat umum dan efek khusus. Efek umum menyangkut efek dasar yang diperkirakan dpat terjdi akibat pesan pesan yang disiarkan melaluli media massa. Komunikasi dapat terjadi akibat pesan pesan yang disiarkan melalui media massa. Komunikasi massa memiliki efek yang "mengembang"sebab dalam banyak hal komunikasi massa telah mengambil alih fungsi komunikasi sosial. Secara umum atau luas, komunikasi massa melalui media massa. Menciptakan masyarakat yang besar dan modern. Efek seperti itu merupakan efek dasar yang terjadi dari hari ke hari secara terus menerus, ia tidak dapat dilihat, didengar atau diraba. Tetapi ia benar benar terjadi. Dapat disimpulkan bahwa terapan media massa pada waktunya kaan menimbulkan perubahan yang mengejutkan. Efek khusus menyangkut efek yang diperkirakan akan timbul pada individu indiidu dalam suatu massa audiens pada perilaku mereka, dalam menerima pesan pesan media massa. Karena ada kombinasi yang berbeda beda antara situasi, kepribadian dan kelompok di antara anggota anggota suatu massa audiens dalam penerimaan pesan, jenis efek yang mungkin timbul (the possible effect) akan berbeda beda pula.

Berdasarkan hal tersebut, dapat disimpulkan bahwa prestasi belajar siswa siswi di sekolah tidak hanya bergantung pada intelegnsi saja melainkan juga tergantung pada factor lain. Salah satunya dalah factor pergaulan anak dalam artian bahwa sifat sosial anak terhadap lingkungan sekitarnya, baik lingkungan sekolah maupun lingkungan masyarakat.

\section{METODE PENELITIAN}

Metode penelitian ini menggunakan ariabel bebas dan terikat (Sumadi Suryabrata, 2014:101) menyatakan bahwa populasi adalah objek penelitian yang diteliti dan mempunyai kualitas serta mempunyai cici yang tidak ditetapkan baik berupa manusia, benda maupun gejala yang ada".

Langkah pengumpulan data yang di anggap sesuai dengan maksud dan tujuan penelitian adalah menggunakan tekhnik dan metode, sesuai dengan sumber data yang diharapkan seperti a=di atas maka di dalam penulisan penelitian ini akan dipakai dan dibahas dua tekhnik pengambilan data yaitu tekhnik dengan metode observasi dan metode dokumentasi.

\section{HASIL PENELITIAN}

Dalam gambaran umum hasil dari penelitian yang nyata dan memuaskan dalam mengumpulkan data, dala bab ini membahasa tentang langkah langkah penelitian yang diawali dengan observasi dan diakhiri dengan dokumentasi, Data yang diperoleh selama penelitian hanya berfungsi sebagai penunjang dari penelitian ini. Dalam hasil penelitian data yang diperoleh oleh penulis bersifat khusus perlu adanya analisa dan diolah sesuai dengan tjuan untuk membuktikan hipotesis dari penelitian. Selain itu data yang diperoleh dari beberapa data yang melalui metode yang mendukung pelaksanaan penelitian antara lain metode observasi dan dokumentasi,

Dari hasil perhitungan data tersebut dapat diketahui bahwa t hitung= 2,88 sedangkan menurut taraf signifikan $5 \%=2,04$ dan $1 \%=2,75$. Dengan demikian nilai t hitung lebih besar dari t tabel pada 
taraf signifikan $5 \%$ dan $1 \%$ sehingga hipotesa kerja (Ha) dapat diterima, sedangkan Hipotesa nihil (Ho) ditolak, artinya ada pengaruh tanyangan kekerasan di teleisi terhadap prestasi siswa sekolah Dasar Negeri Lerpak 1 keamatan Geger Kabupaten Bangkalan.

\section{KESIMPULAN DAN SARAN KESIMPULAN:}

Berdasarkan hasil dari penelitian yang dilaksanakan dapat disimpulan bahwa "ada pengaruh tanyangan kekerasan di televise dengan prestasi siswa di sekolah dasar SDN Lerpak 3 Kecamatan Geger Kabupaten Bangkalan.

SARAN:

Berdasarkan hasil penelitian ini, peneliti menyarankan hal-hal sebagai berikut:

1. Kepada orang tua siswa dapat menanamkan sikap disiplin. Anak hendaknya lebih dilandasi dengan sikap rasa tanggung jawab, cinta kasih saying, karena dengan sikap tersebut hubungan orang tua dan anak bisa harmonis dan kondusif.

2. Kepada guru di sekolah hendaknya dalam melaksanakan pembinaan semnagat belajar kepada siswa hendaknya diciptakan suatu pola pembinaan yang terpadu antara sekolah, keluarga dan masyarakat, karena kita ketahui ketiga factor tersebut merupakan lingkungan interaksi anaka yang tidak bisa dipisahkan.

3. Kepada semua insane yang ada kaitannya dengan rasa pedulinya terhadap pendidikan hendaknya lebih baik selalu mencari solusi terbaik mengenai upaya peningkatan prestasi belajar siswa sehingga siswa dapat mencapai prestasi yang optimal.

\section{DAFTAR PUSTAKA}

Arikunto Suharsimi,2014. Prosedur Penelitian suatu Pendekatan Praktek, Jakarta, Rineka Cipta

Departemen P dan K RI,2012. Kamus Besar Bahasa Indonesia, Jakarta.

Hadi Sutrisno,2014, Sattistik 2, Yayasan Peneribit Fakultas Psikologi UGM,Yogyakarta

Indra Kusuma Amir, 2015. Pengantar Ilmu Pendidikan , Usaha Nasional, Malang

Kartono, Kartini,2013. Peranan Keluarga Memandu Anak, rajawali pers, Jakarta

Rostiawati Yustiana,2015. Dasar Dasar Ilmu Pendidikan, PT. Ramedia Pustaka Utama, Jakarta

Sutrisno, Joko Subandowo, M.Suyono, 2016. Buku Pedoman Penelitian, Usaha Nasional, Malang

Suwarno ,2012. Pengantar Umum Pendidikan, Rineka Cipta, Jakarta

Tim Dosen FKIP- Malang, 2013.Pengantar Dasar-Dasar Kependidikan, Usaha Nasional, Surabaya. 